BMJ Open Sport \& Exercise Medicine

\title{
Priorities for injury prevention in women's Australian football: a compilation of national data from different sources
}

\author{
Lauren V Fortington, Caroline F Finch
}

To cite: Fortington LV, Finch CF. Priorities for injury prevention in women's Australian football: a compilation of national data from different sources. BMJ Open Sport Exerc Med 2016;2: 000101.

doi:10.1136/bmjsem-2015000101

- Prepublication history for this paper is available online. To view these files please visit the journal online (http://dx.doi.org/10.1136/ bmjsem-2015-000101).

Accepted 15 June 2016

CrossMark

Australian Collaboration for Research into Injury in Sport and its Prevention (ACRISP), Federation University Australia, Ballarat, Victoria, Australia

Correspondence to Dr Lauren Fortington; I.fortington@federation.edu.au

\section{ABSTRACT}

Background/aim: Participation in Australian football (AF) has traditionally been male dominated and current understanding of injury and priorities for prevention are based solely on reports of injuries in male players. There is evidence in other sports that indicates that injury types differ between males and females. With increasing participation in AF by females, it is important to consider their specific injury and prevention needs. This study aimed to provide a first injury profile from existing sources for female AF.

Methods: Compilation of injury data from four prospectively recorded data sets relating to female AF: (1) hospital admissions in Victoria, 2008/09-13/14, $\mathrm{n}=500$ injuries; (2) emergency department (ED) presentations in Victoria, 2008/09-2012/13, $n=1,879$ injuries; (3) insurance claims across Australia 20042013, n=522 injuries; (4) West Australian Women's Football League (WAWFL), 2014 season club data, $\mathrm{n}=49$ injuries. Descriptive results are presented as injury frequencies, injury types and injury to body parts.

Results: Hospital admissions and ED presentations were dominated by upper limb injuries, representing $47 \%$ and $51 \%$ of all injuries, respectively, primarily to the wrist/hand at $32 \%$ and $40 \%$. Most $(65 \%)$ insurance claim injuries involved the lower limb, 27\% of which were for knee ligament damage. A high proportion of concussions $(33 \%)$ were reported in the club-collected data.

Conclusions: The results provide the first compilation of existing data sets of women's AF injuries and highlight the need for a rigorous and systematic injury surveillance system to be instituted.

\section{INTRODUCTION}

Australian football (AF) is a popular, fast-paced team sports involving running, jumping and tackling with frequent change in speed and direction. ${ }^{1}{ }^{2}$ Typically a maledominated sport, the number of females playing AF has increased substantially over recent years with over 285000 women and girls participating in 2015 in a structured

\section{Summary of new findings}

This is the first compilation of existing data for injuries sustained by women who play Australian football (AF).

- In women's AF, lower limb injuries are most common in insurance data, upper limb injuries most common in hospital data and head injuries are most common in club-collected data.

- Gaps in available data suggest that rigorous and systematic injury surveillance is justified to gain a more complete and accurate profile of female AF injuries.

programme or competition at introductory (Auskick), school, club or elite levels across Australia. ${ }^{3}$ An elite, national competition for females will begin in 2017. ${ }^{3}$ At senior levels, women's $\mathrm{AF}$ is played under the same rules as the men's game, with the exception of using a slightly smaller sized ball. At junior levels, modified versions of the game (restricted tackling and smaller field/ball) are in place for both boys and girls. ${ }^{4}$

As with all sports participating in AF exposes players to a risk of injury. The substantive body of research relating to $\mathrm{AF}$ injuries in male elitelevel players and, to a lesser extent, community male adult and junior players has recently been summarised based on different data collection methods to identify priorities for injury prevention. $^{5-8}$ From prospective, field-based data collections, lower limb muscle strains, together with superficial injuries (eg, bleeding, lacerations), were identified as the most common community AF injury in males (both adults and children). ${ }^{7}$ When considering injuries in male AF players from studies that have used data based on having received medical attention, upper limb injuries are the most prevalent, comprising $36-43 \%$ of hospital admissions and $37-53 \%$ of emergency 
department (ED) presentations, with injury types largely comprising fractures and dislocations. ${ }^{6}$

There is reasonable evidence in other team ball sports to suggest that the number and nature of injuries sustained by females differ from those sustained by males. For example, conservative estimates of anterior cruciate ligament (ACL) injuries in team ball sports such as soccer and basketball report females having 2-3 times greater numbers of ACL injuries than males. ${ }^{9-11}$ Similarly, several systematic reviews have reported sex differences in reported concussion incidence, ${ }^{12-16}$ risk factors $^{13} 1718$ and outcomes. ${ }^{12} 19{ }^{20}$ In light of these findings, in other sports it is reasonable to think that there may be differences in the types of injuries sustained by male and female participants of AF.

Following the structure proposed in the Translating Research into Injury Prevention Practice (TRIPP) model, the dominant injuries in female AF participants need to be identified before developing an understanding of the causes of these injuries so that steps can be taken towards their prevention. ${ }^{21}$ The current study was undertaken to gain a first understanding of injuries compiled from multiple sources of existing data, which inherently document different types of injuries. Specifically, the aim of this paper was to describe the number, injury type and body location for commonly reported injuries in female $\mathrm{AF}$ participants.

\section{METHODS}

Data on injuries sustained while participating in AF were extracted from three routinely collected injury databases and one single-season league-wide injury data collection. Key features of the databases identified are summarised in table 1. Information sought from the data sets for comparison included:

- Body region injured (eg, upper limb, lower limb);

- Body part injured (eg, knee, ankle);

- Nature of injury (eg, laceration, fracture).

Any additional information relating to the cases (state/region played, age or age group) and to the injuries (text narrative, mechanism) was extracted where it was available. Since sources differed in the level of detail presented in the injury descriptions, the data needed to be coded into a consistent format. All information from the club-based data and insurance data were provided at case level while the hospital data were provided as aggregated counts of each variable. This format allowed a broad-level comparison of injuries across data sets. A descriptive analysis of the frequency and types of injuries sustained is presented for all data sources.

\section{RESULTS}

\section{Australiawide insurance claims}

There were 522 injury insurance claims from 2004 to 2013 by females for football-related injuries across Australia. Most claims (65\%) were for lower limb injuries, involving joint damage (ie, ligament tears and dislocations) or muscle injuries (tears and strains) (12\%; table 2). The category of 'other' lower limb injuries was also large $(10 \%)$. Upper limb fractures $(10 \%)$ and upper limb joint damage $(8 \%)$ made up the remaining of the most frequent injuries. The most frequent specific claim was for knee ligament injuries, accounting for a total of $141(27 \%)$ cases. No further detail on the type of ligament injury, for example, whether it was the anterior cruciate or medial ligament, was available.

\section{Victoria-hospital-treated cases}

In Victoria, there were 500 hospital admissions relating to football injuries in females. Girls aged 15-19 years (31\%) and 10-14 years (24\%) comprised the largest proportion of injured cases. Hospital admissions most often involved the upper limb $(47 \%)$ and the type of injury was reported most commonly as fractures (51\%) or joint damage $(21 \%)$.

Just over half $(51 \%)$ of ED presentations involved the upper limb, of which $78 \%$ were wrist/hand injuries, $11 \%$ elbow/forearm and $11 \%$ shoulder/upper arm. The most frequent types of injuries treated at an ED were joint damage (47\%) and fractures $(25 \%)$.

\section{Western Australia-league-reported cases}

There were 49 injuries reported for 43 players (2 injuries were reported in 5 players and 3 injuries in 1 player) from 7 clubs. One-third of reported injuries (33\%) were concussion. Joint damage comprised 27\% of injuries, mainly involving the knee and ankle. Of the 49 injuries, $40 \%$ presented to hospital.

\section{DISCUSSION}

This study was aimed at Stage 1 of the TRIPP framework to gain an understanding of injuries from existing data to shape future injury prevention research and practice for females playing $\mathrm{AF}^{21}$ It is important to establish the nature of the injury problem in female $\mathrm{AF}$, before the relevance of existing injury prevention measures that have been developed for the men's game can be questioned. Through an analysis of four existing data sets, capturing different expected injuries in terms of severity, a profile of the most common injuries reported and treated in female AF was developed for the first time. Across each data source, as expected there was variation in the types of injuries captured, reflecting the types of injuries presenting to each source: lower limb in the insurance data upper limb in hospital data and head injuries in the club data. Insurance claim injuries tend to be for lower limb joint damage as they are more costly to fix and therefore players pursue an injury claim while hospitals/EDs treat people immediately for upper limb fractures. Despite data sources tending to be biased toward specific injury types, these injuries are still important to consider in detail as they are reflective of 
Table 1 Key data collection features of included data sets for female Australian football injuries

\begin{tabular}{|c|c|c|c|c|}
\hline & JLT sport* & $\begin{array}{l}\text { Victorian Admitted } \\
\text { Episodes Dataset }^{\star *}\end{array}$ & $\begin{array}{l}\text { Victorian Emergency } \\
\text { Minimum Dataset }^{\star *}\end{array}$ & $\begin{array}{l}\text { West Australian } \\
\text { Women's Football } \\
\text { League }\end{array}$ \\
\hline Data source & Insurance claims cases & Hospital admissions & $\begin{array}{l}\text { Emergency } \\
\text { presentations }\end{array}$ & Club-based collection \\
\hline $\begin{array}{l}\text { Injuries } \\
\text { included }\end{array}$ & $\begin{array}{l}\text { Injuries which had costs } \\
\text { that were not covered by } \\
\text { Australia's public health } \\
\text { system (eg, elective } \\
\text { medical procedures such } \\
\text { as non-urgent surgeries) } \\
\text { or resulted in a substantial } \\
\text { loss of income }\end{array}$ & $\begin{array}{l}\text { Injuries which required } \\
\text { admission to a hospital }\end{array}$ & $\begin{array}{l}\text { Injuries for which a } \\
\text { person sought treatment } \\
\text { at an ED }\end{array}$ & $\begin{array}{l}\text { Any self-reported injury } \\
\text { sustained during games } \\
\text { (no specific definition } \\
\text { was provided). Injuries } \\
\text { were reported by players } \\
\text { to club trainers, with } \\
\text { differing experience and } \\
\text { qualifications }\end{array}$ \\
\hline $\begin{array}{l}\text { Data } \\
\text { extraction }\end{array}$ & $\begin{array}{l}\text { All cases of injuries in the } \\
\text { football-related database } \\
\text { were extracted, } \\
\text { subsequently only the } \\
\text { player-related injuries were } \\
\text { analysed (injury cases } \\
\text { sustained in non-playing } \\
\text { related activities were not } \\
\text { included) }\end{array}$ & $\begin{array}{l}\text { Victorian Injury } \\
\text { Surveillance Unit } \\
\text { extracted cases for } \\
\text { females with ICD-10-AM } \\
\text { activity code U5000 } \\
\text { (Australian Rules } \\
\text { Football) or U5008 } \\
\text { (other specified football) } \\
\text { or U5009 (football } \\
\text { unspecified) }\end{array}$ & $\begin{array}{l}\text { Victorian Injury } \\
\text { Surveillance Unit } \\
\text { extracted all data for } \\
\text { females with a text } \\
\text { narrative that included } \\
\text { the term 'football' or } \\
\text { variations and } \\
\text { derivatives. Cases were } \\
\text { manually checked for } \\
\text { relevance }\end{array}$ & Not applicable \\
\hline Age range & All & All & All & 16 years plus \\
\hline Location & Australia-wide & Victoria & Victoria & Western Australia \\
\hline $\begin{array}{l}\text { Population } \\
\text { coverage }\end{array}$ & $\begin{array}{l}\text { Players engaged in } \\
\text { football participation } \\
\text { (training and games) }\end{array}$ & $\begin{array}{l}\text { State-wide collection of } \\
\text { data on all admissions to } \\
\text { Victorian public and } \\
\text { private hospitals }\end{array}$ & $\begin{array}{l}39 \text { Victorian public } \\
\text { hospital EDs, inclusive of } \\
\text { all public hospitals with a } \\
24 \mathrm{~h} \text { service }\end{array}$ & $\begin{array}{l}\text { Players in the Western } \\
\text { Australian Women's } \\
\text { Football Leagues- } \\
\text { premier, reserve and } \\
\text { youth (if over } 16 \text { years) }\end{array}$ \\
\hline $\begin{array}{l}\text { Dates } \\
\text { included }\end{array}$ & $\begin{array}{l}\text { January 2004-December } \\
2013\end{array}$ & July 2008-June 2014 & July 2008-June 2013 & April-August 2014 \\
\hline $\begin{array}{l}\text { Associated } \\
\text { information } \\
\text { available }\end{array}$ & $\begin{array}{l}\text { Area and club played, } \\
\text { injury type, date of injury, } \\
\text { playing surface, body } \\
\text { region injured, month, } \\
\text { weather, age, injury } \\
\text { narrative }\end{array}$ & $\begin{array}{l}\text { Injury type, body region } \\
\text { injured, body part } \\
\text { injured, player age, } \\
\text { cause, location injury } \\
\text { occurred, length of stay }\end{array}$ & $\begin{array}{l}\text { Injury type, body region } \\
\text { injured, body part } \\
\text { injured, player age, } \\
\text { cause, location injury } \\
\text { occurred }\end{array}$ & $\begin{array}{l}\text { Date of injury, venue, } \\
\text { age, injury, pre-existing } \\
\text { injury, cause, treatment } \\
\text { required, timing of injury } \\
\text { in game, expected } \\
\text { weeks out of game, } \\
\text { injury narrative }\end{array}$ \\
\hline $\begin{array}{l}\text { Number of } \\
\text { records } \\
\text { included }\end{array}$ & 522 & 500 & 1879 & 49 \\
\hline Case capture & $\begin{array}{l}100 \% \text { (based on JLT being } \\
\text { the insurance provider of } \\
\text { all AF clubs) }\end{array}$ & $\begin{array}{l}100 \% \text { (based on } \\
\text { information provided by } \\
\text { the Victorian Injury } \\
\text { Surveillance Unit) }\end{array}$ & $\begin{array}{l}89 \% \text { (based on } \\
\text { information provided by } \\
\text { the Victorian Injury } \\
\text { Surveillance Unit) }\end{array}$ & Unknown \\
\hline
\end{tabular}

*JLT Sport is a division of Jardine Lloyd Thompson Pty Limited.

**Data from VAED and VEMD was obtained from the Victorian Injury Surveillance Unit.

ED, emergency department.

cases that have a high individual health and economic burden.

\section{Lower limb injuries}

Lower limb joint injuries were within the top two body regions in all data sources. When looking into the narratives and detail of these injuries, where available, many were reported to be ligamentous injuries of the knee.
The prevention of knee injuries in females is a wellknown priority for all sports where jumping, landing, cutting and rapid change of direction is required. ${ }^{22}$ Because of the relatively serious outcomes associated with ACL injury, which often requires surgery and time off sport, these injuries have been extensively researched in team ball sports particularly in relation to genderbased risk factors including anatomical and 
Table 2 Frequency and proportions of body injured region and injury type by different data sources Australia-wide

\begin{tabular}{|c|c|c|c|c|}
\hline & $\begin{array}{l}\text { Insurance } \\
\text { claims n (\%) }\end{array}$ & $\begin{array}{l}\text { Hospital } \\
\text { admissions n (\%) }\end{array}$ & $\begin{array}{l}\text { Emergency } \\
\text { presentations n (\%) }\end{array}$ & $\begin{array}{l}\text { Club based } \\
\text { n (\%) }\end{array}$ \\
\hline \multicolumn{5}{|l|}{ Body region } \\
\hline Face, head, neck & $40(7.6)$ & $117(23.4)$ & 309 (16.4) & $19(38.8)$ \\
\hline Trunk & $23(4.4)$ & $11(2.2)$ & $56(3.0)$ & * \\
\hline Lower limb & $340(65.1)$ & $122(24.4)$ & $512(27.2)$ & $18(36.7)$ \\
\hline Upper limb & 107 (20.5) & $237(47.4)$ & 958 (51.0) & 9 (18.4) \\
\hline Other & $12(2.3)$ & $0(0)$ & $32(1.7)$ & * \\
\hline \multicolumn{5}{|l|}{ Injury type } \\
\hline Superficial & $10(1.9)$ & $7(1.4)$ & $202(10.8)$ & * \\
\hline Fracture & 101 (19.3) & $253(50.6)$ & $464(24.7)$ & $9(18.4)$ \\
\hline Joint damage & $238(45.6)$ & $107(21.4)$ & 875 (46.6) & $13(26.5)$ \\
\hline Muscle & 64 (12.3) & $20(4.0)$ & $108(5.7)$ & * \\
\hline Concussion & $5(1.0)$ & $49(9.8)$ & 61 (3.2) & $16(32.7)$ \\
\hline Other & 104 (19.9) & $54(10.8)$ & $159(8.5)$ & * \\
\hline
\end{tabular}

biomechanical differences. ${ }^{23}$ While incidence rates of knee injury vary by sport, they are consistently higher in females than males. ${ }^{24-26}$ The increased risk varies by age, sport and whether players have exposure to a preventative training programme. ${ }^{27}$ It is likely that females who play AF will also have a higher risk of knee injuries than men, and specifically, a higher risk of ACL injury. Although research from other sports provides some insights towards knee injury prevention, specific research focused on females who play $\mathrm{AF}$ is recommended to confirm the mechanism behind these injuries. It is important to understand the mechanism of injury not only because of the apparent high number and burden of these injuries and also because strong evidence exists to support AF-specific injury prevention measures targeted at the player/sport, including rule changes ${ }^{28}$ or specific exercise training programmes. ${ }^{29-34}$

\section{Upper limb injuries}

Wrist, hand and finger injuries (including dislocations, fractures and sprains) appear to have a high treatment burden with half of all ED presentations being for upper limb injuries. This finding is supported by research in Ladies Gaelic football, a sport featuring many similarities to $\mathrm{AF}$, where females have reported a relatively high proportion of finger fractures compared to other injuries. ${ }^{35-37}$ Limited information was available on the mechanism of this injury, with the hospital and ED data suggesting either 'falls' or 'being hit/stuck/crushed' as the underlying cause. This raises questions of whether players are hit/struck in a tackle situation or if players' hands are incorrectly positioned when taking a mark (catching the ball) and are subsequently hit by the ball. Similarly, are players falling awkwardly on an outstretched arm when landing from a jump or being tackled? Little information on the cause or mechanism of upper limb injuries is available in the literature and they stand out as a target area for understanding of the mechanism of injury and how these injuries might be prevented.

\section{Concussion}

There was a very high proportion of concussion injuries in the WAWFL data (33\%) and also a relatively high proportion from the hospital admissions (10\%). In community men's AF, concussions generally represent $3-4 \%$ of all injuries. ${ }^{38-41}$ It is possible that the WAWFL data reflect recent efforts to promote awareness of the injury from the sport's peak body and a fear surrounding the injury outcomes driving greater reporting of the injury. However, a higher incidence of concussion has been reported for females, compared with males, in other team ball sports. ${ }^{12-16}$ Given the somewhat high proportions of apparent concussion in female AF, further insight to the number and mechanism of these injuries certainly warrants investigation. There is currently very limited information on mechanism of concussion in community AF for either males or females, so measures aimed at preventing the specific game-situations that lead to concussion cannot be suggested with confidence. ${ }^{41}$ Until specific information is known, female AF players and their coaches, should be encouraged to follow existing AFL concussion management guidelines. $^{42}$ In addition, it might be useful for coaches, trainers and players to recognise concussion as a significant injury in females who play $\mathrm{AF}$ and that it may take longer for females to fully recover and return to play.

\section{Limitations}

This analysis of existing data sources provided a relatively quick and inexpensive method for gaining valuable novel insight to female injuries in AF. The hospital and insurance data sets were chosen on the basis of the authors' prior experience with them. To supplement these, the club-based data were suggested by the AFL Women's League as the only club-based surveillance effort to date. 
While the efforts of the WAWFL to set up a prospective club-based injury collection are commendable, there appeared to be a tendency to report only the most severe of injuries or considered to be high-risk, given the high proportion of concussions. All injuries in the WAWFL were self-reported, with no confirmation of medical diagnosis. A reliance on club volunteers and limited medical resources can be challenging enough to a competition without the added burden of injury reporting, so incentives to participate and education on the importance of reporting all injuries might be required. ${ }^{43}$

The Victorian Admitted Episodes Dataset (VAED) and the Victorian Emergency Minimum Dataset are only available for one state (Victoria) and provide information only on the subset of more severe injuries that is, those requiring emergency and hospital management. Errors in coding and classification can occur and therein present either an overestimation or underestimation of injury frequency. ${ }^{44}$ For example, in the VAED, it is standard to recode 'unspecified football' codes to $\mathrm{AF}$ based on the assumption that it is the most common sport for the region. However, it is possible that these cases could include other football codes (soccer, touch football, rugby, etc), thereby providing an overestimate of admissions related to AF. In contrast, cases may not have been coded for activity at all, which can be the case in an ED setting, therein underestimating the injury frequency. Data are provided as aggregate results, meaning that while age groups are identified, they are not linked to specific injury types, just the number of events so more detailed analyses were not possible. However, the injuries in the hospital data sets were common in younger age groups and likely reflective of higher participation rates among youth participants. More broadly, the compiled data sets mainly covered injuries considered as acute or traumatic, that is, hospital and insurance data. Therefore, overuse or chronic-onset injuries may have been largely missed along with injuries that were managed at a community health level, for example by a general practitioner or physiotherapist.

While drawing on these existing data sources provides insight to injury types and body regions affected, the sources offer no data relating to player exposure to injury and therefore injury incidence rates were not able to be calculated. Similarly, the data are limited, in that it provided no detail on the severity of injury or the impact of the injury to players' ongoing participation. Furthermore, the data limitations precluded us from making formal comparisons to injury data from other sports settings. These limitations support a need to implement an ongoing, prospective injury surveillance system in female AF across all levels of participation.

\section{CONCLUSION}

The data available to report are likely to underrepresent female AF participants and are unlikely to be completely accurate, yet, importantly they do provide a first indication that some of the risks for females, in terms of types of injury sustained, may be different in both magnitude and nature to those reported in the male form of the sport. These existing data sets provided some basic information about the key injuries in female AF, but it is very clear that there is an immediate need to undertake formal injury surveillance in this rapidly developing form of the game.

Twitter Follow Lauren Fortington at @lfortington and Caroline Finch @CarolineFinch

Acknowledgements The authors thank Dr Alex Donaldson for his work on the broader FootyWISE project and Jan Cooper, Female Football Development Manager, for her support of the project. The authors thank the Victorian Injury Surveillance Unit (VISU) at Monash University, JLT Sport (a division of Jardine Lloyd Thompson Pty Ltd), and the Western Australian Women's Football League, for provision of data used in this study. ACRISP is one of the International Research Centres for the Prevention of Injury and Protection of Athlete Health supported by the International Olympic Committee (IOC).

Contributors LVF and CFF designed the study, collected and analysed the data and prepared the manuscript for publication.

Funding The study was funded by the Australian Football League (AFL) Research Board. The AFL had no input to the conduct of the study or interpretation of results. Caroline Finch is funded by a National Health and Medical Research Council (NHMRC) Principal Research Fellowship (ID1058737).

\section{Competing interests None declared.}

Ethics approval The project was approved by the Federation University Human Research Ethics Committee (approval number C15-001).

Provenance and peer review Not commissioned; externally peer reviewed.

Data sharing statement No additional data are available.

Open Access This is an Open Access article distributed in accordance with the Creative Commons Attribution Non Commercial (CC BY-NC 4.0) license, which permits others to distribute, remix, adapt, build upon this work noncommercially, and license their derivative works on different terms, provided the original work is properly cited and the use is non-commercial. See: http:// creativecommons.org/licenses/by-nc/4.0/

\section{REFERENCES}

1. Australian Bureau of Statistics. Feature article 1: Football: Four games, one name. Secondary Feature article 1: Football: Four games, one name. http://www.abs.gov.au/AUSSTATS/abs@.nsf/ Previousproducts/4156.0.55.001Feature\%20Article1May\%202009? opendocument\&tabname $=$ Summary \&prodno $=4156.0 .55$. $001 \&$ issue $=$ May\%202009\&num $=\&$ view $=$ (accessed 10 March 2016)

2. Australian Football League. Laws of the game. Secondary Laws of the game. http://www.afl.com.au/laws (accessed 9 March 2016).

3. Australian Football League. 118th Annual Report. 2014 http://www. afl.com.au/afl-hq/annual-reports (accessed 11 November 2015).

4. Australian Football League. Womens Football Match Guide. Secondary Womens Football Match Guide. http://www. aflcommunityclub.com.au/fileadmin/user_upload/Play_AFL/ Multicultural/AF_2842_1014_Womens_Football_Match_Guide_web_ lores.pdf (accessed 9 May 2016).

5. Chalmers S, Magarey ME, Scase E. Junior Australian football injury research: are we moving forward? Phys Ther Sport 2013;14:175-82.

6. Ekegren CL, Gabbe BJ, Finch CF. Medical-attention injuries in community Australian football: a review of 30 years of surveillance data from treatment sources. Clin J Sports Med 2015;25:162-72.

7. Finch CF, Gabbe B, White $P$, et al. Priorities for investment in injury prevention in community Australian football. Clin J Sport Med 2013;23:430-8.

8. Orchard JW, Seward H, Orchard JJ. Results of 2 decades of injury surveillance and public release of data in The Australian Football League. Am J Sports Med 2013;41:734-41. 
9. Beynnon BD, Vacek PM, Newell MK, et al. The effects of level of competition, sport, and sex on the incidence of first-time noncontact anterior cruciate ligament injury. Am J Sports Med 2014;42:1806-12.

10. Waldén $\mathrm{M}$, Hägglund $\mathrm{M}$, Magnusson $\mathrm{H}$, et al. Anterior cruciate ligament injury in elite football: a prospective three-cohort study. Knee Surg Sports Traumatol Arthrosc 2011:19:11-19.

11. Prodromos $\mathrm{CC}$, Han $\mathrm{Y}$, Rogowski J, et al. A meta-analysis of the incidence of anterior cruciate ligament tears as a function of gender, sport, and a knee injury-reduction regimen. Arthroscopy 2007;23:1320-25.e6.

12. Dick RW. Is there a gender difference in concussion incidence and outcomes? Br J Sports Med 2009;43(Suppl 1):i46-50.

13. Maher ME, Hutchison M, Cusimano M, et al. Concussions and heading in soccer: a review of the evidence of incidence, mechanisms, biomarkers and neurocognitive outcomes. Brain Inj 2014;28:271-85.

14. Harmon KG, Drezner J, Gammons M, et al, American Medical Society for Sports Medicine. American Medical Society for Sports Medicine position statement: concussion in sport. Clin J Sports Med 2013;23:1-18.

15. Covassin T, Swanik CB, Sachs ML. Sex differences and the incidence of concussions among collegiate athletes. J Athl Train 2003;38:238-44.

16. Hootman JM, Dick R, Agel J. Epidemiology of collegiate injuries for 15 sports: summary and recommendations for injury prevention initiatives. $J$ Athl Train 2007:42:311-19.

17. Abrahams S, Fie SM, Patricios J, et al. Risk factors for sports concussion: an evidence-based systematic review. Br J Sports Med 2014:48:91-7.

18. Noble JM, Hesdorffer DC. Sport-related concussions: a review of epidemiology, challenges in diagnosis, and potential risk factors. Neuropsychol Rev 2013;23:273-84.

19. King NS. A systematic review of age and gender factors in prolonged post-concussion symptoms after mild head injury. Brain Inj 2014;28:1639-45.

20. Covassin T, Elbin RJ, Crutcher B, et al. The management of sport-related concussion: considerations for Male and female athletes. Trans/ Stroke Res 2013;4:420-4.

21. Finch C. A new framework for research leading to sports injury prevention. J Sci Med Sport 2006;9:3-9.

22. Sugimoto D, Myer GD, Micheli LJ, et al. ABCs of evidence-based anterior cruciate ligament injury prevention strategies in female athletes. Curr Phys Med Rehabil Rep 2015;3:43-9.

23. Shultz SJ, Schmitz RJ, Benjaminse A, et al. ACL research retreat VII: an update on anterior cruciate ligament injury risk factor identification, screening, and prevention. J Athl Train 2015;50:1076-93.

24. Mall NA, Chalmers PN, Moric M, et al. Incidence and trends of anterior cruciate ligament reconstruction in the United States. Am J Sports Med 2014;42:2363-70.

25. Parkkari J, Pasanen K, Mattila VM, et al. The risk for a cruciate ligament injury of the knee in adolescents and young adults: a population-based cohort study of 46500 people with a 9 year follow-up. Br J Sports Med 2008;42:422-6.

26. Arendt EA, Agel J, Dick R. Anterior cruciate ligament injury patterns among collegiate men and women. $J$ Athl Train 1999;34:86-92.
27. Joseph AM, Collins CL, Henke NM, et al. A multisport epidemiologic comparison of anterior cruciate ligament injuries in high school athletics. J Athl Train 2013;48:810-17.

28. Orchard JW, Seward H. Decreased incidence of knee posterior cruciate ligament injury in Australian Football League after ruck rule change. Br J Sports Med 2009;43:1026-30.

29. Hübscher $\mathrm{M}$, Zech $\mathrm{A}$, Pfeifer $\mathrm{K}$, et al. Neuromuscular training for sports injury prevention: asystematic review. Med Sci Sport EX 2010;42:413-21.

30. Hübscher M, Refshauge KM. Neuromuscular training strategies for preventing lower limb injuries: what's new and what are the practical implications of what we already know? Br J Sports Med 2013:47:939-40.

31. Soligard T, Myklebust G, Steffen K, et al. Comprehensive warm-up programme to prevent injuries in young female footballers: cluster randomised controlled trial. BMJ 2008;337:a2469.

32. Myklebust G, Engebresten L, Braekken IH, et al. Prevention of anterior cruciate ligament injuries in female team handball players: a prospective intervention study over three seasons. Clin J Sports Med 2003;13:71-8.

33. Petersen W, Braun C, Bock W, et al. A controlled prospective case control study of a prevention training program in female team handball players: the German experience. Arch Orthop Trauma Surg 2005;125:614-21.

34. Mandelbaum BR, Silvers HJ, Watanabe DS, et al. Effectiveness of a neuromuscular and proprioceptive training program in preventing anterior cruciate ligament injuries in female athletes: 2-year follow-up. Am J Sports Med 2005;33:1003-10.

35. Brown J, Papadopoulos C, Pritchett R. Examination of injury in female gaelic football. Int J Exerc Sci 2013;6:98-105.

36. Crowley J, Jordan J, Falvey E. A comparison of gaelic football injuries in males and females in primary care. Irish Med $J$ 2011;104:268-70.

37. O'Rourke KP, Quinn F, Mun S, et al. A comparison of paediatric soccer, gaelic football and rugby injuries presenting to an emergency department in Ireland. Injury 2007;38:104-11.

38. Ekegren CL, Gabbe BJ, Donaldson A, et al. Injuries in community-level Australian football: results from a club-based injury surveillance system. J Sci Med Sports 2015;18:651-5.

39. Braham R, Finch CF, McCrory P. The incidence of head/neck/ orofacial injuries in non-elite Australian Football. J Sci Med Sports 2004:7:451-3.

40. Gabbe B, Finch $\mathrm{C}$, Wajswelner $\mathrm{H}$, et al. Australian football: Injury profile at the community level. J Sci Med Sports 2002;5:149-60.

41. Fortington L, Twomey D, Finch C. Concussion in community Australian football-epidemiological monitoring of the causes and immediate impact on play. Inj Epidem 2015;2:20.

42. Australian Football League. Concussion. Secondary Concussion. http://www.aflcommunityclub.com.au/index.php?id=66 (accessed 21 November 2015).

43. Ekegren C, Donaldson A, Gabbe B, et al. Implementing injury surveillance systems alongside injury prevention programs: evaluation of an online surveillance system in a community setting. Inj Epidem 2014;1:19.

44. Finch CF, Boufous S. Do inadequacies in ICD-10-AM activity coded data lead to underestimates of the population frequency of sports/ leisure injuries? Inj Prev 2008;14:202-4. 